УДК 378: 338.4(510+477)

(C) Ду Цзінсюй, 2020

https://orcid.org/0000-0002-7337-5167

https://doi.org/10.34142/23128046.2020.48.03

Ду Цзінсюй

\title{
ПОРІВНЯЛЬНА ХАРАКТЕРИСТИКА СТАНУ РОЗРОБЛЕНОСТІ ПРОБЛЕМИ ФОРМУВАННЯ ПІДПРИЕМНИЦЬКОЇ КОМПЕТЕНТНОСТІ СТУДЕНТІВ ВИЩОЇ ШКОЛИ В КНР ТА УКРАЇНI
}

У статті констатовано, щуо в КНР проблема формування підприємницької компетентності в молоді ефективно вирішується на державному рівні, унаслідок чого підприємництво перетворилося на один із найважливіших стратегічних факторів інтенсивного розвитку національної економіки. У таких умовах доцільним кроком для українських освітян $\epsilon$ творче використання теоретичних та практичних доробок китайських фахівців з окресленої проблеми. Тому тема статті є дійсно актуальною.

Як установлено, окремі аспекти проблеми формування підприємницької компетентності студентів вищьӧ иколи розкрито в працях таких учених, як: А. Агеєв, Ван Хуей, Л. Земка, Чэжан Хуйхуа та ін. Проте вченими не проводився порівняльний аналіз стану розробленості проблеми формування підприємницької компетентності студентів вищої иколи у КНР та Україні.

Мета та завдання статті: на основі аналізу китайської й украӥнської наукової літератури та практичного досвіду з формування підприємницької компетентності студентів вищої школи навести порівняльну характеристику стану розробленості зазначеної проблеми в Китайській народній республічі та Україні. У дослідженні використовувались теоретичні методи (аналіз, порівняння, узагальнення, систематизація) для опрацювання наукової літератури з досліджуваної проблеми та практичні методи (спостереження, анкетування, бесіди) для вивчення відповідного освітнього досвіду.

У статті зазначено, щуо у вищій школі КНР викладаються різні навчальні курси, реалізуються державні й міжнародні освітні програми та проекти з окресленої проблематики. У позааудиторний час для майбутніх фахівиів також організовуються зустрічі з успішними бізнесменами та проводяться майстер-класи, конкурси стартапів, консультування висококваліфікованих фахівціів тощуо. У публікації також з'ясовано, щзо українськими авторами визначено й реалізовано на практиці конкретні шляхи, засоби, педагогічні умови, методи формування підприємницької компетентності студентів у вищій школі України. 
У подальшому дослідженні планується виявити перспективні напрями використання доробок китайських педагогів із проблеми формування підприємницької компетентності студентів вищої школи в умовах освітніх реалій України.

Ключові слова: підприємницька компетентність, порівняльна характеристика, студент, вища школа, КНР, Украӥна.

Du Jingxu. The comparative characteristics of the state of problem's development of the students' entrepreneurial competence formation of higher education in China and Ukraine. The article states that in the CPR, the problem of forming entrepreneurial competence in youth is effectively solved at the state level, resulting in entrepreneurship becoming one of the most important strategic factors for the intensive development of the national economy. In such circumstances, it is an appropriate step for Ukrainian educators to use creatively theoretical and practical developments on the outlined problem of Chinese specialists. Therefore, the chosen topic of the article is really relevant.

As it was established, some aspects of the problem's development of the students' entrepreneurial competence formation of higher education are disclosed in the works of such scholars as A. Ageev, Wang Hui, L. Zemka, Zhang Huhua and others. However, a comprehensive comparative analysis of the state of problem's development of the students' entrepreneurial competence formation was not conducted in China and Ukraine by the scientists.

The aim and tasks: on the basis of the analysis of the Chinese and Ukrainian scientific literature and the practical experience of forming the entrepreneurial competence of the students of higher education give a comparative characteristic of the state of development of the problem in the People's Republic of China and Ukraine. The study used the theoretical methods like (analysis, comparison, generalization, systematization) to study the scientific literature on the problem and practical methods (observation, questionnaires, interviews) for the processing relevant educational experience.

It was indicated in the article that different educational courses are taught at the Chinese higher education institution, as well as national and international educational programs and outlined projects. Out of class time meetings with successful businessmen and their workshops, start-up competitions, consulting of highly qualified specialists, etc are also organized for future professionals. It was found out in the publication that the Ukrainian authors have identified and implemented in practice specific ways, means, pedagogical conditions, methods of forming the entrepreneurial competence of students in higher education in Ukraine.

In the further study it is planned to identify promising directions of using the achievements of Chinese teachers on of problem's development of the students' entrepreneurial competence formation of higher education in the educational realities of Ukraine. 
Keywords: entrepreneurial competence, comparative characteristics, student, high school, Chinese People's Republic, Ukraine.

Вступ. Активний розвиток ринкових відносин в українському суспільстві зумовив докорінну трансформацію всіх сфер його життєдіяльності. У свою чергу, це вимагає від кожного закладу вищої освіти забезпечити конкурентоспроможність його випускників на сучасному ринку праці. Необхідною передумовою успішного вирішення зазначеного завдання $\epsilon$ формування у студентів вищої школи підприємницької компетентності.

У світлі викладеного варто зауважити, що в КНР проблема формування вказаної компетентності в молоді ефективно вирішується на державному рівні, що дало змогу перетворити підприємництво у зазначеній країні на один із найважливіших стратегічних факторів інтенсивного розвитку національної економіки. У таких умовах доцільним кроком для українських освітян $\epsilon$ творче використання теоретичних та практичних доробок 3 окресленої проблеми китайських фахівців. Тому обрана тема статті $є$ дійсно актуальною.

Під час проведення дослідження з'ясовано, що в науковій літературі КНР та України знайшли відображення окремі аспекти проблеми формування підприємницької компетентності студентів вищої школи, зокрема такі: суть підприємницької компетентності особистості (А. Агеєв, Ю. Білова, Ван Хуей, О. Пискун, С. Прищепа, Чжан Хуйхуа та ін.), структура цієї компетентності (Л. Земка, Джи Ючао, Лін Хайтао та ін.), шляхи та способи формування підприємницької компетентності у студентської молоді (Джі Ючао, В. Майковська, Г. Назаренко, М. Стрельніков, Чжан Хуйхау та ін.), методи, форми, засоби формування зазначеної компетентності в майбутніх фахівців різних спеціальностей (Лін Хайтао, Н. Каландирець, С. Мельник, Н. Побірченко та ін.).

Воднораз під час наукових розвідок було встановлено, що вченими не проводився комплексний порівняльний аналіз стану розробленості проблеми формування підприємницької компетентності студентів вищої школи у вказаних країнах. Проте проведення такого аналізу $\epsilon$ необхідною передумовою для визначення можливості застосування напрацювань китайських науковців для подальшої розробки теоретичних основ розв'язання зазначеної проблеми в умовах українських освітніх реалій.

Мета та завдання. На основі аналізу китайської й української наукової літератури та практичного досвіду 3 формування підприємницької компетентності студентів вищої школи навести порівняльну характеристику 
стану розробленості зазначеної проблеми в Китайській народній республіці та Україні.

Методи дослідження. Під час проведення дослідження використовувались теоретичні методи (аналіз, порівняння, узагальнення, систематизація) для опрацювання наукової літератури 3 досліджуваної проблеми та практичні методи (спостереження, анкетування, бесіди) для вивчення відповідного освітнього досвіду, що дало змогу скласти порівняльну характеристику стану теоретичної розробленості проблеми формування підприємницької компетентності студентів вищої школи в Китаї та Україні.

Результати. Як установлено в процесі дослідження, проблема формування підприємницької компетентності студентів вищої школи знаходиться в центрі уваги багатьох китайських та українських учених $\mathrm{i}$ педагогів-практиків.

Так, Чжань Шуньхуей відзначає, що підприємництво є провідною ланкою економічної системи КНР. За висновками автора, малий бізнес здійснює суттєвий вплив на соціально-економічний розвиток Китаю, що проявляється насамперед у таких тенденціях, як:

- висока частка зайнятості населення Китаю в царині підприємництва сприяє розв'язанню проблеми безробіття й активному розвитку продуктивних сил у китайському суспільстві;

- приватна економіка дає змогу підвищити ефективність використання наявних ресурсів через включення в обіг бездіяльних громадських фондів;

- підприємництво забезпечує прискорення розвитку сфери послуг у країні;

- бізнес гнучко реагує на будь-які зміни ситуації на ринку, а як наслідок - підприємці спроможні швидко й адекватно діяти на основі врахування зовнішніх вимог суспільства;

- підприємництво сприяє зростанню загальної продуктивності праці в Китаї, а також підвищенню відповідальності бізнесменів при виборі й інвестуванні певних проєктів (Shunhuej, 2007).

Як установлено в дослідженні, у КНР проводиться цілеспрямована політика щодо залучення молоді до підприємницької діяльності. Причому відповідна підготовка до цієї діяльності проводиться зі студентами не тільки економічних, але й решти спеціальностей. Така підготовка забезпечує формування в студентської молоді підприємницької компетентності, що дає змогу всім бажаючим у майбутньому розпочати власний бізнес у галузі 
отриманої спеціальності. 3 цією метою у вищій школі КНР викладаються різні навчальні курси, реалізуються державні й міжнародні освітні програми та проєкти з окресленої проблематики. Наприклад, студенти можуть пройти міжнародну освітню програму «Знай про бізнес».

Значну увагу розв'язанню досліджуваної проблеми викладачі приділяють також під час організації позааудиторної діяльності студентів. Так, для них організують зустрічі 3 успішними бізнесменами 3 демонстрацією відповідних майстер-класів, конкурси стартапів та інші заходи. Крім того, майбутні фахівці завжди можуть звернутися за допомогою (юридичною, економічною, інформаційною та ін.) до працівників Центрів підтримки малого й середнього підприємництва, а також отримати в цих центрах додаткову освіту 3 питань організації власного бізнесу. Популярністю у студентів користуються і вузькопрофільні курси з навчання молоді веденню підприємницької діяльності (Lingling, 2016; Zongxin, 2017).

Важливо підкреслити, що в процесі навчання бізнесу майбутнім фахівцям не тільки викладають загальні основи його ведення, але й пропонують конкретні рекомендації для різних практичних ситуацій. Наприклад, студентам нагадають, що ключем до успіху роздрібної торгівлі $\epsilon$ не стільки якість товару, скільки місце розташування продавця для пропонування цього товару потенційним покупцям. Тому бажаючим відкрити магазини чи кафе пропонують такі цінні поради: під час вибору приміщення необхідно віддавати перевагу тим 3 них, які знаходяться в діловому чи культурному районі, навіть за умови, що за таке приміщення доведеться платити більш високу оренду. По-можливості, обирати кутовий будинок та розміщувати вивіски з обох боків. Крім того, на вулиці, де торгівельні точки знаходяться з обох сторін, варто обирати місце справа, бо люди йдуть 3 правої сторони вулиці, а тому більше уваги звертають на ті магазини чи кафе, які знаходяться прямо перед їхніми очами (Kak nachat biznes i vesti malyj biznes s nedostatochnymi sredstvami, 2019).

У дослідженні також з'ясовано, що китайські студенти, які планують навчатися в іншій країні та воднораз розпочати там певний бізнес, можуть отримати консультації кваліфікованих фахівців щодо особливостей ведення бізнесу в цій країні. Наприклад, у Канаді сьогодні навчається понад 100 тисяч китайців. Тому для майбутніх фахівців, які навчаються в канадських університетах, було розроблено конкретні рекомендації: як обрати перспективну галузь для підприємницької діяльності в Канаді, як зареєструвати там свою фірму та успішно займатися бізнесом паралельно 3 
навчанням у вищій школі. Причому студентам пропонувалося спочатку з’ясувати, чи дозволяє видана їм для навчання віза займатися в Канаді підприємницькою діяльністю. Якщо така можливість іноземцям надавалася, їм пропонувалося вивчати поради фахівців та успішний досвід інших студентів.

Так, китайські студенти тяжіють до традиційної домашньої іжі, тому для підприємців перспективною справою для бізнесу є організація імпорту продукції вітчизняних заводів до Канади та експорту північноамериканської спеціалізованої продукції до КНР. Підприємцям-початківцям наводились також приклади успішного ведення студентського бізнесу в Канаді. Так, у Китаї деякі студенти займаються виробництвом світлодіодних світильників та іншої дрібної побутової техніки на дому. Це дало змогу організувати спільний бізнес майбутніх фахівців, які навчаються у КНР та Канаді, що передбачає імпорт товарів для дому для продажу в Північній Америці.

Автором розроблених рекомендацій також наводився такий приклад: окремі студенти китайських університетів працюють у сфері громадського харчування на дому. Це стало підставою для створення спільного проєкту групи цих студентів та студентів з Канади, суть якого полягає в експорті до КНР канадського вина, лобстерів, морепродуктів тощо.

Як констатувалося в третьому наведеному прикладі, студенти, які вивчають комп'ютерні спеціальності в університеті чи просто $\epsilon$ добре обізнаними фахівцями в комп'ютерних технологіях, традиційно залучаються до інтернет-підприємництва. Окремі студенти-підприємці створюють різні міжнародні компанії для обслуговування різних потреб студентської молоді чи міжнародні асоціації студентів, займаються репетиторством тощо.

Підсумуємо, що проведення викладачами вищої школи описаної роботи зі студентам дозволяє їм краще зорієнтуватися в реаліях чужої країни та переконатися в наявності широких можливостей для заняття власним бізнесом у Канаді (Kak inostrannye studenty nachinayut biznes v Kanade, 2020).

Отже, можна констатувати, що в Китаї створена цілісна, добре продумана система формування підприємницької компетентності студентів. Ïї реалізація не тільки дозволяє майбутнім фахівцям успішно оволодіти загальними знаннями й уміннями здійснення підприємницької діяльності, але й сприяє максимально ефективному застосовуванню в ній сформованих у вищій школі фахових компетентностей людини.

Як з'ясовано в процесі дослідження, в останні роки проблема формування підприємницької компетентності студентів вищої школи стала 
також об’єктом досліджень багатьох українських учених. У світлі цього В. Гейць зазначає, що прискорення економічного розвитку країни сьогодні не можна забезпечувати шляхом економії коштів на задоволення особистісних потреб громадян. Більш того, автор уважає, що саме витрачання коштів на економічну просвіту членів суспільства, забезпечення цілеспрямованого формування в них підприємницької компетентності є найбільш вигідним способом для вкладання державних інвестицій (Sotsialno-ekonomichnyi stan Ukrainy: naslidky dlia narodu ta derzhavy, 2009).

Ідеї вказаного вище автора знайшли подальший розвиток у дисертації М. Ткаченка. У зазначеній науковій праці автор наголошує, що сучасне суспільство потребує компетентних фахівців, які відрізняються добре сформованими знаннями щодо ведення підприємницької діяльності та вміннями генерувати нестандартні ідеї у своїй професійній сфері, ефективно спілкуватися 3 діловими партнерами, здійснювати свідомий вибір у проблемних ситуаціях, реалізувати постійне професійне самовдосконалення. Тому автор вважає за необхідне забезпечити здійснення цілеспрямованого розвитку підприємницької компетентності у студентів вищої школи, що $є$ необхідною передумовою формування в них спроможності започаткувати власний бізнес та стати в подальшому успішним підприємцем (Tkachenko, 2018).

Як стверджує О. Земка, в останні десятиріччя підприємництво перетворилось в Україні в найважливіший стратегічний ресурс та воднораз внутрішнє джерело подальшого розвитку ринкової економіки. Тому важливо забезпечити цілеспрямоване формування в молодого покоління підприємницької компетентності. Результатом цього процесу має стати підготовка фахівців, які добре орієнтуються в господарській царині, демонструють підприємницькі знання та відповідні вміння (генерувати й реалізовувати на практиці нові бізнес-ідеї, грамотно планувати, організовувати та здійснювати підприємницьку діяльність), а також здатність до творчого мислення, інноваційності, виправданого ризику (Zemka, 2017).

В іншій статті авторкою визначено, що успішність формування підприємницької компетентності майбутніх фахівців забезпечується створенням таких педагогічних умов, як: посилення позитивної мотивації студентів до практики підприємництва та підготовки їх до самостійної господарської діяльності; досягнення цілісності й неперервності процесу формування в майбутніх фахівців підприємницької компетентності шляхом забезпечення інтеграції змісту різних навчальних дисциплін та основ 
підприємництва; формування в майбутніх фахівців значущих підприємницьких якостей i здатностей засобами здійснення відповідної підготовки; викладання спецкурсу «Основи підприємницької діяльності»; залучення студентів до виконання завдань, спрямованих на формування підприємницької компетентності (Zemka, 2017).

М. Ляшенко теж вважає, що чільне місце у процесі формування підприємницької компетентності студентів слід відвести викладанню їм спецкурсу «Основи підприємницької діяльності». Як пояснює авторка, це сприятиме оволодінню майбутніми фахівцями комплексом знань із основ підприємництва та здійснення управління маркетинговою діяльністю в цій сфері, а також практичними вміннями до ведення власного бізнесу, розвитку економічного мислення студентів (Liashenko, 2016).

Обговорення. Результати наукових розвідок $\epsilon$ підставою для ствердження, що формування підприємницької компетентності студентів вищої школи знаходиться в центрі уваги багатьох науковців КНР та України. Проте в Китаї педагогічна діяльність в окресленому напрямі носить більш систематизований характер.

Висновки. На підставі проведеного порівняльного аналізу стану розробленості проблеми формування підприємницької компетентності студентів вищої школи в КНР та Україні зроблено висновок про те, що в українській вищій школі дійсно можна творчо застосувати доробки китайських педагогів з окресленої проблеми. У подальшому дослідженні планується конкретизувати перспективні напрями використання цих напрацювань в умовах освітніх реалій України.

\section{ЛІТЕРАТУРА:}

Земка О. В. Критерії, показники та рівні сформованості підприємницької компетентності у майбутніх учителів технологій. Вісник [Глухів. нац. пед. ун-ту імені Олександра Довженка]. Сер.: Педагогічні науки. 2017. Вип. 1. С. 101-110.

Земка О. В. Педагогічні умови формування підприємницької компетентності майбутніх учителів технологій. Вісник [Черкас. ун-ту]. 2017. Вип. 15. С. 48-53.

Ляшенко М. Формування підприємницької компетентності у майбутніх учителів технологій. Наукові записки: зб. наук. пр. Кіровоград. держ. пед. ун-ту імені Володимира Винниченка. Серія: Проблеми методики фізико-математичної $\mathrm{i}$ технологічної освіти. Кропивницький: Кіровоград. держ. пед. ун-т імені В. Винниченка, 2016. Вип. 9(3). С. 51-54.

Соціально-економічний стан України: наслідки для народу та держави: національна доповідь. Київ, 2009. 687 с.

Ткаченко М. В. Формування підприємницької компетентності майбутніх фахівців ресторанного господарства у професійно-технічних навчальних закладах: дис. ... канд. пед. наук: 13.00.04. Київ, 2018. 347 с. 
Чжань Шуньхуэй. Особенности организации предпринимательства в Китае. Экономика и политика. 2007. № 2(27). С. 21-23.

王宗信 著. 中高职贯通人才培养模式研究. 的上海, 2017.

留学生如何在加拿大创业经商? (2020)

Режим

доступу :

https://zhuanlan.zhihu.com/p/63602459.

藏玲玲. 国际视野下的高校创业教育课程研究. 的北京, 2016.310頁.

资金不足的情况下做生意怎么起步，如何做小本生意. (2019) Режим доступу：

http://www.xuexiai.com/shengyixuexi/22504.html.

\section{REFERENCES:}

Chzhan Shunhuej (2007). Osobennosti organizacii predprinimatelstva $v$ Kitae [The he organization features of business in China]. Ekonomika i politika. № 2(27). P. 21-23. (in Russian).

Kak inostrannye studenty nachinayut biznes $v$ Kanade? (2020). [How do international students start a business in Canada?] Retrieved from: https://zhuanlan.zhihu.com/p/63602459. (in Chinese)

Kak nachat biznes $i$ vesti malyj biznes s nedostatochnymi sredstvami (2019). [How to start a business and run a small business with insufficient funds]. Retrieved from: http://www.xuexiai.com/shengyixuexi/22504.html. (in Chinese)

Liashenko, M. (2016). Formuvannia pidpryemnytskoi kompetentnosti u maibutnikh uchyteliv tekhnolohii. [The entrepreneurial competence formation of a future teachers' technology]. Naukovi zapiski: zb. nauk. pr. Kirovohrad. derzh. ped. un-tu imeni Volodymyra Vinnichenka. Seriia: Probleme metodyky fiziko-matematychnoi i tekhnolohichnoi osvity. Kropyvnytskii: Kirovohrad. derzh. ped. un-t imeni V. Vinnichenka. Vip. 9(3). P. 51-54. (in Ukranian).

Sotsialno-ekonomichnyi stan Ukrainy: naslidky dlia narodu ta derzhavy: natsionalna dopovid (2009). [The Socio-Economic Situation of Ukraine: Implications for the People and the State: A National Report]. Kyiv. (in Ukranian).

Tkachenko, M. V. (2018). Formuvannia pidpryemnitskoi kompetentnosti maibutnikh fakhivtsiv restorannoho hospodarstva u profesiino-tekhnichnykh navchalnykh zakladakh [The entrepreneurial competence formation of future specialists of restaurant industry in vocational schools]. (Candidate's thesis). Kyiv, Ukraine. (in Ukranian).

Van Zongxin (2017). Issledovanie modeli obucheniya talantov vysshego professionalnogo obrazovaniya. [The research of the model of talents training of higher vocational education]. Shanhaj. (in Chinese)

Zang Lingling. (2016). Issledovanie uchebnoj programmy po predprinimatelstvu $v$ universitetah $s$ mezhdunarodnoj tochki zreniya. [The international curriculum of the entrepreneurship study at the Universities from the international point of view]. Beijing, Press. (in Chinese)

Zemka, O. V. (2017). Kryterii, pokaznyky ta rivni sformovanosti pidpryemnytskoi kompetentnosti u maibutnikh uchiteliv tekhnolohii [Criteria, indicators, and levels of the entrepreneurial competence for a future teachers' technology]. Visnik [Gluhiv. nac. ped. un-tu imeni Oleksandra Dovzhenka]. Ser.: Pedagogichni nauki. Vip. 1. P. 101-110. (in Ukranian).

Zemka, O. V. (2017). Pedahohichni umovy formuvannia pidpryemnytsoi kompetentnosti maibutnikh uchiteliv tehnolohii [Pedagogical conditions of the entrepreneurial competence formation of a future teachers' technology]. Visnik [Cherkas. un-tu]. Vip. 15. P. 48-53. (in Ukranian). 
Інформація про автора:

Ду Цзінсюй:

ORCID: https://orcid.org/0000-0002-7337-

5167; аспірант кафедри загальної педагогіки

i педагогіки вищої школи Харківського національного педагогічного університету імені Г.С. Сковороди, вул. Валентинівська, 2, м. Харків, Україна 61166.

e-mail: $841672071 @ q q . c o m$
Information about the author:

Du Jingxu:

ORCID: https://orcid.org/0000-0002-73375167; graduate student of General Pedagogy Department and the Pedagogy of Higher School H. S. Skovoroda Kharkiv National Pedagogical University, Valentynivska street, 2, Kharkiv, Ukraine 61166.

e-mail: 841672071@qq.com

Цитуйте цю статтю як: Ду Цзінсюй Порівняльна характеристика стану розробленості проблеми формування підприємницької компетентності студентів вищої школи в КНР та Україні. Теорія та методика навчання та виховання. 2020. № 48. С.32-41.

DOI: https://doi.org/10.34142/23128046.2020.48.03

Дата надходження статті до редакції:

Стаття прийнята до друку: 